\title{
THE VALIDITY EVIDENCE OF TOEFL TEST AS PLACEMENT TEST
}

\author{
Ayu Liskinasih \\ Fakultas Bahasa dan Sastra Universitas Kanjuruhan Malang \\ J1. S. Supriyadi 48 malang, Indonesia \\ Phone: (+62) 85646456050 e-mail: ayuliskinasih@gmail.com \\ Rizky Lutviana \\ Fakultas Bahasa dan Sastra Universitas Kanjuruhan Malang \\ Jl. S. Supriyadi 48 malang, Indonesia \\ Phone: (+62) 8123251962 e-mail: lutviana.rizky@unikama.ac.id
}

\begin{abstract}
This study is aimed at evaluating the validity of TOEFL test as instrument for placement test. The three sections of the test including listening, structure, reading, and vocabulary were used to measure 96 freshmen basic competences in English, before attending courses. Based on the result of TOEFL test, students were classified into four classes from the highest to the lowest competency levels, namely A, B, C, and $\mathrm{D}$. To measure the correlation level, the two sets of score were compared by using Pearson product moment correlation, the TOEFL score and students' achievement score. The score of students' achievement was derived from the final test of Integrated Course. There were 2 language skills and 2 language components that were tested: listening, reading, grammar and vocabulary. The medium positive and significant correlation level (0.41) indicated that TOEFL test was quiet valid to be used as instrument for placement test. However, students' characteristics and background should be considered to achieve the high and significant correlation level.
\end{abstract}

Keywords: placement test, TOEFL test, and validity

\section{INTRODUCTION}

In order to improve the quality of education, since 2015, University Kanjuruhan of Malang has required freshman to take placement test before joining Integrated Course. Integrated Course is the required course that students should take in the first semester. The main purpose of placement test is to place students based on different levels of competences. Students with the same proficiency level will be put in the same class.

Putting students in the same competence level of classes will ease the job of teaching. It will be easier for the lecturers to manage class and to design the most suitable materials and teaching method. If there is problem in teaching and learning process, the lecturer can decide the effective strategy that works for most students. Moreover, for students, it reduces peer pressure, and students will be comfortable learning with classmates who have the same competences.

TOEFL Test is commonly used as placement test in a University, especially in English Department Program. There are two types of TOEFL test, namely Computer Based (CB) TOEFL Test and Paper Based (PB) TOEFL Test. Both CB and PB TOEFL test consist of four sections including listening 
section, structure section, reading section, and writing section. In this study, the TOEFL test that is used for placement test is PB TOEFL test that consisted of three sections, listening section, structure section, and writing section.

There are some considerations in using TOEFL test as placement test: (1) TOEFL test is one of standardize tests that is ready to use so that the lecturer could save time and energy, (2) TOEFL test is constructed in multiple choice item test format so that it is easy for the lecturer to score students' language competence, and (3) TOEFL test used standardize scoring method so that the lecturer does not need to construct criteria for scoring.

Despite its benefits, some researchers argued the validity of TOEFL test as instrument for placement test. Belfield \& Crosta (2012) and also Scott-Clayton (2012) found negative correlation between placement test score and students' achievement. Additionally, Saxon \& Morante (2014) criticize the practice of placement test, he noticed that: (1) students do little preparation before test, (2) students lack of knowledge on the material as well as the format of the test, and (3) placement test does not measure students' potential in learning.

Regarding this critique it is necessary to review the validity of TOEFL test as the instrument for placement test. Commonly the institution classified students only based on score derived from the placement test without knowing the accuracy of this policy. Moreover, less studies have been done to investigate the validity placement test decision. Based on this research gap, the purpose of this study is to review the validity of TOEFL test as instrument for placement test.

\section{Methods}

This research used correlation design. There were seven research steps: (1) documenting placement test scores; (2) conducting data analysis using descriptive analysis and normality test Kolmogorov-Smirnov; (3) documenting post-test result; (4) analyzing post test data using descriptive analysis and normality test (Kolmogorov-Smirnov); (5) determining appropriate correlation statistic technique; (6) conducting hypothesis test; and (7) taking conclusion. There were four classes in the population with distinct characteristics; thus, this research applied stratified random sampling. The researchers took 40 samples from the total 102 subjects in the population. 10 samples were randomly taken from each class.

\section{FINDINDS}

Integrated course is the course that students should take in the beginning of the study. The purpose of this course is to develop students' proficiency in the intermediate level of English. To make it work, students were classified into classes with different competency levels. In this case, students who had the same proficiency level were placed in the same class. The purpose of this policy is to ease the job of teaching and to help students to learn easily. Placing students with the same proficiency level will make them comfortable in learning. The test used to classify students based on different levels of proficiency was Paper Based TOEFL Test.

\section{Validity Evidence of Paper Based TOEFL Test}

Validity in testing and assessment means "measures accurately what it is intended to measure" (Hughes, 1989: 22). In this study, two variables to be measured were score of placement test and achievement test. These two variables basically measured the same thing that was students' proficiency. In this case, PB TOEFL test was considered valid if it measured students' language proficiency. In learning language, students' proficiency is regarded as the degree of skill with which a person can use a language, such as how well a person can read, write, speak, or understand language (Richards \& Schmidt, 2010).

The support for validity evidence in this study was criterion validity. In this case the validity evidence is the strength of the predictive relationship between the test score and that performance on the criterion (Fulcher \& Davidson, 2007: 5). Despite the fact that there are four language skills (listening, 
speaking, reading, and writing) and three language components (vocabulary, grammar, and pronunciation), the two language skills (listening and reading) and two language components (vocabulary and grammar) were used as language performance criterion in this study.
The Paper Based TOEFL test used in this study consisted of sections: listening, structure, and reading and vocabulary. There were 140 items test that students needed to complete, and they were given 140 minutes to finish, Table 1 showed the result of students' score.

\begin{tabular}{|c|c|c|c|c|c|}
\hline No. & Range of Score & Frequency & Percentage & Class & Category \\
\hline 1. & $297-343$ & 24 & $25 \%$ & $\mathrm{D}$ & Low \\
\hline 2. & $344-363$ & 25 & $26 \%$ & $\mathrm{C}$ & Mediocre \\
\hline 3. & $364-380$ & 23 & $24 \%$ & B & Good \\
\hline \multirow[t]{2}{*}{4.} & $381-463$ & 24 & $25 \%$ & A & Excellent \\
\hline & Total & 96 & $100 \%$ & & \\
\hline
\end{tabular}

Tabel 1. Students' Score on Placement Test

In Table 1, based on Paper Based

TOEFL score, students were classified into four classes, from the lowest to the highest competence levels, namely D, C, B, and A. Students with the range score 297-343 belonged to class $\mathrm{D}$, the low proficiency class; students with the range score 344-363 belonged to the $\mathrm{C}$ class, who were considered mediocre class; students with the range score 364-380 belonged to B class, the good class; while students with the range score 381-463, were A class, the excellent class.

To check whether Paper Based TOEFL score really represents students' proficiency, the students' score on Paper Based TOEFL
Test is compared with students' achievement score after following Integrated Course for 6 months. In Integrated Course students learned to develop their skills in English, including listening, speaking, reading, and writing; as well as the language components including vocabulary, grammar integratedly. However, for the purpose of this study, the students' score on achievement was derived from the score of listening, reading, grammar, and vocabulary. Table 2 and Figure 1 showed the mean score of Paper Based TOEFL test and the mean score of students' achievement on Integrated Course for each class.

\begin{tabular}{ccc}
\hline Class & $\begin{array}{c}\text { Mean Score of } \\
\text { Placement Test (TOEFL) }\end{array}$ & $\begin{array}{c}\text { Mean Score of Students' } \\
\text { Achievement on Integrated } \\
\text { Course }\end{array}$ \\
\hline D & 331 & 74 \\
C & 355 & 77 \\
B & 372 & 79 \\
A & 407 & 82
\end{tabular}

Table 2. Mean Score of Placement Test and Achievement Test 


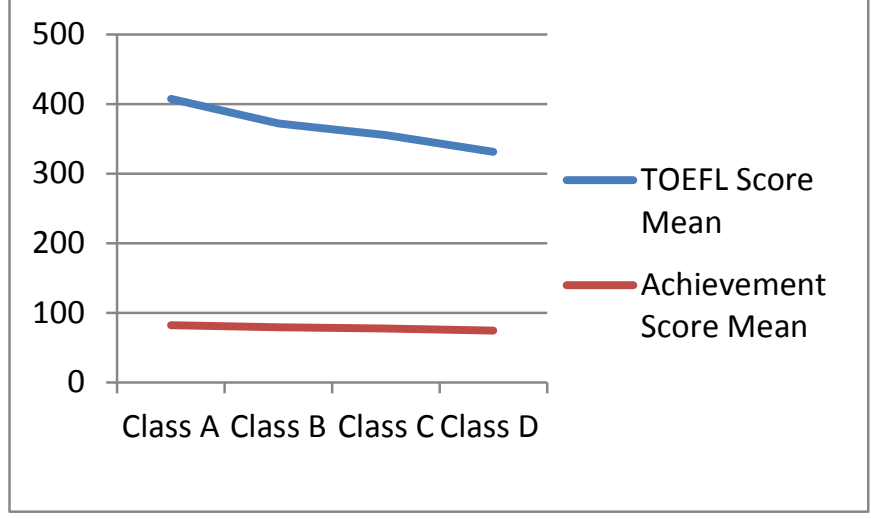

Figure 1. Mean Score of Placement Test and Achievement Test

The improvement score on Paper Based TOEFL test is in line with the improvement of students' achievement score. It can be inferred that paper based TOEFL test accurately measure students' proficiency and accurately placed students in the right class. The A class students, who were considered as the excellent student got the highest mean of achievement score, and vice versa, the $\mathrm{D}$ class students got the lowest mean of achievement score. These findings were also indicated by the correlation level

\section{Placement Test Students' Achievement (TOEFL Test) score Score}

1 $.417^{* * *}$

Sig. (2-tailed)

Sum of Squares and Crossproducts

84692.500

9342.375

Covariance

891.500

98.341

$\mathrm{N}$

Students' Achievement

Pearson Correlation

Sig. (2-tailed)

96

96

$.417^{* *}$

.000

Sum of Squares and Crossproducts

9342.375

5915.156

Covariance

98.341

62.265

96

**. Correlation is significant at the 0.01 level (2-tailed).

Tabel 3. Correlation Level Using Pearson Product Moment

Table 3 showed a positive and significant correlation point, that was 0.417 . It was significant since the significance level was less than 0.05 that was 0.0 . This point indicated moderately strong relationship between placement test score and students' achievement score (Lodico et al, 2010:284).

Class D

Descriptive Statistics

\begin{tabular}{|c|c|c|c|c|c|c|c|c|}
\hline & & & & & & \multicolumn{3}{|c|}{ Percentiles } \\
\hline & $\mathrm{N}$ & Mean & Std. Deviation & Minimum & Maximum & $25^{\text {th }}$ & $\begin{array}{c}\text { 50th } \\
\text { (Median) }\end{array}$ & $75^{\text {th }}$ \\
\hline PBT TOEFL TEST & 24 & 331.542 & 12.21538 & 297.00 & 343.00 & $3.2375 \mathrm{E} 2$ & 335.0000 & $3.4225 \mathrm{E} 2$ \\
\hline
\end{tabular}




\begin{tabular}{|c|c|c|c|c|c|c|c|c|}
\hline \multicolumn{9}{|c|}{ Descriptive Statistics } \\
\hline & & & & & & & Percentiles & \\
\hline & $\mathrm{N}$ & Mean & Std. Deviation & Minimum & Maximum & $25^{\text {th }}$ & $\begin{array}{c}\text { 50th } \\
\text { (Median) }\end{array}$ & $75^{\text {th }}$ \\
\hline PBT TOEFL TEST & 24 & 331.542 & 12.21538 & 297.00 & 343.00 & $3.2375 \mathrm{E} 2$ & 335.0000 & $3.4225 \mathrm{E} 2$ \\
\hline $\begin{array}{l}\text { STUDENTS' } \\
\text { ACHIEVEMENT } \\
\text { SCORE }\end{array}$ & 24 & 74.3333 & 7.36423 & 53.00 & 89.00 & 70.2500 & 75.0000 & 80.0000 \\
\hline
\end{tabular}

Table 4. The Summary of Students' Score in Class D

Class D consisted of 24 students, the lowest score was 53 while the highest score was 89 . Most students in this class had low proficiency; they needed to learn Basic English. Some students explained that they did not get proper English lesson in Senior High School, thus it was difficult for them to follow the lesson. Moreover, there were 4 students who got score below 70. Based on the observation done by researcher, students' characteristics influenced their achievement. Those students who got score below 70 were not motivated and tended to be passive in learning. They were not willing to help themselves in learning. However, there were 3 students who got score above 80 ; they had high motivation in learning. They tended to be active in learning.

Class C

Descriptive Statistics

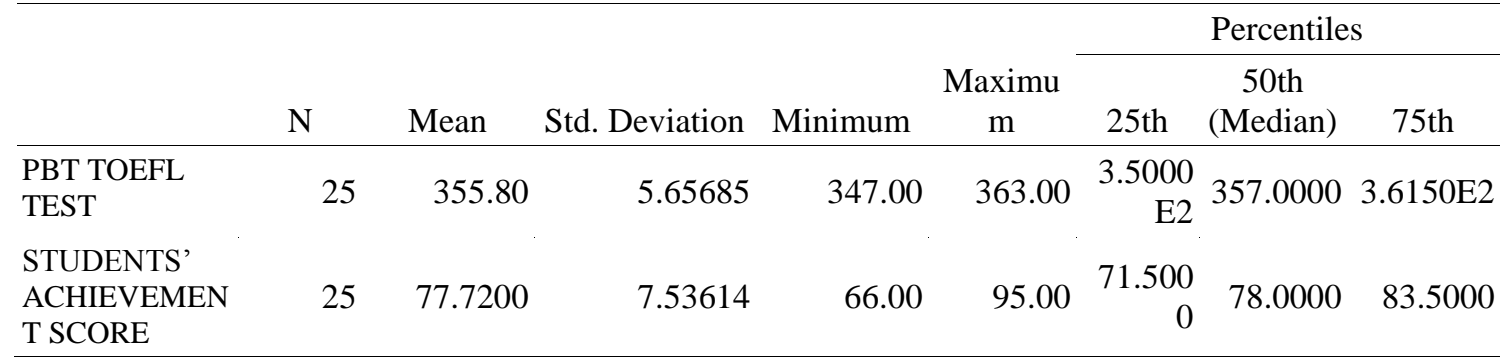

Table 5. The Summary of Students' Score in Class C

Class $\mathrm{C}$ consisted of 25 students with the range score of 347-363 for Paper Based TOEFL test score. This was the mediocre class, students' proficiency was considered slightly better than students on D class. However, different from class D, class C sowed the lower standard deviation score, meaning that variant score was low. It could be inferred that students in this class showed generally the same progress in learning. Students who got good score on placement test mostly also got the good score on final test of Integrated Course. Most students in this class still needed to learn the basic English, especally grammar and vocabulary. It was hard for them to understand reading text and spoken monologue and dialogue.

Class B

\section{Descriptive Statistics}

N Mean Std. Minimum Maximu Percentiles 


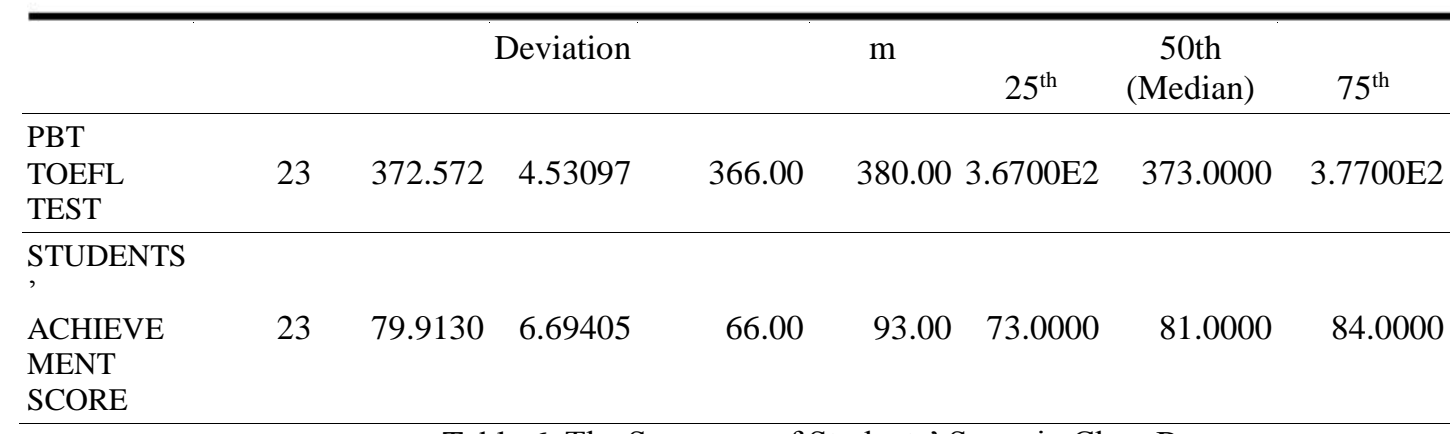

Table 6. The Summary of Students' Score in Class B

Class B was regarded as the second best class. The mean score for PBT TOEFL test was 372 and the mean score for achievement test was 79. Only 1 student in this class got score below 70 , based on observation done by researcher, this student was not motivated in learning and frequently skipped classes. However, most students in this class were generally performed well during lesson. They were active and mostly were able to follow the lecturers' instruction.

Class A

\begin{tabular}{|c|c|c|c|c|c|c|c|c|}
\hline \multicolumn{9}{|c|}{ Descriptive Statistics } \\
\hline & \multirow[b]{2}{*}{$\mathrm{N}$} & \multirow[b]{2}{*}{ Mean } & \multirow[b]{2}{*}{$\begin{array}{c}\text { Std. } \\
\text { Deviation }\end{array}$} & \multirow[b]{2}{*}{ Minimum } & \multirow[b]{2}{*}{$\begin{array}{l}\text { Maximu } \\
\mathrm{m}\end{array}$} & \multicolumn{3}{|c|}{ Percentiles } \\
\hline & & & & & & $25^{\text {th }}$ & $\begin{array}{c}\text { 50th } \\
\text { (Median) }\end{array}$ & $75^{\text {th }}$ \\
\hline $\begin{array}{l}\text { PBT TOEFL } \\
\text { TEST }\end{array}$ & 24 & 407.29 & 17.53129 & 386.00 & 463.00 & $3.9400 \mathrm{E} 2$ & 407.0000 & 4.1300E2 \\
\hline $\begin{array}{l}\text { STUDENTS' } \\
\text { ACHIEVEMENT } \\
\text { SCORE }\end{array}$ & 24 & 82.5000 & 7.96187 & 66.00 & 95.00 & 76.2500 & 82.0000 & 87.7500 \\
\hline
\end{tabular}

Table 7. The Summary of Students' Score in Class A

This was the excellent class with the highest mean score for PBT TOEFL test that was 407 and the highest mean score for achievement test that was 82 . There was only 1 student in this class got score below 70 that was 66 . Based on the observation done by researcher, this student actually had a good capacity in learning but she tended to be passive, therefore her achievement was not improved. However, most students in this class were fast in learning new material; they already had a good Basic English knowledge. Thus, the lecturer sometimes gave additional lesson and assignment that was slightly more difficult for students in other classes. 


\section{CONCLUSION}

To sum up, this study outlined two important findings. Firstly, there were moderately strong positive correlation (0.417) between placement test (PBT TOEFL Test) score and students" achievement score on Integrated Course. It showed by the tendency that the increase score on placement test (PBT TOEFL test) followed by the increase on students' achievement score in Integrated Course. It can be inferred that PBT TOEFL test is valid instrument for placement test, the students' class reflected students' proficiency before attending course.

Secondly, in some cases students from excellent class did not perform better in learning, and vice versa, students from the low class performed better in learning. There was another factor contributed students' achievement on learning that was students' characteristics and background. Students from the lowest class could perform better if they had high motivation in learning, and conversely, students from the excellent class got low score on achievement if they were passive in learning. Moreover, students who received good and appropriate English lesson on High School performed well on test, and vice versa, students from the lowest class generally performed low on placement test because they did not get Basic English lesson on Senior High School. Therefore, for the future researcher it is necessary to address the effect of students' characteristics and background on the validity of TOEFL test as placement test.

\section{REFERENCES}

Belfield, C.R. \& Crosta, P.M. (2012). Predicting Success in College: The Importance of Placement Test and High School Transcript. (CCRC Working Paper No. 42). New York, NY: Columbia University, Teachers College, Community Research Center.

Brown, H.D. (2004). Language Assessment: Principles and Classroom Practices. White Plains, NY: Pearson Education.

Creswell, J.W. (2012). Educational Research Planning, Conducting and Evaluating Quantitative and Qualitative Research. Boston: Pearson.

Fulcher, G. \& Davidson, F. 2007. Language Testing and Assessment: An Advanced Resource Book. Oxon: Routledge.

Jack, C.R. \& Schimdt, R. 2010. Longman Dictionary of Language Teaching and Applied Linguistics 4th Edition. England: Longman.

Lodico et al. (2010). Methods in Educational Research. San Francisco: Jossey-Bass.

Saxon, D.P. \& Morante, E.A. (2014). Effective Student Assessment and Placement:

Challenges and Recommendations. Journal of Developmental Education, 37(3): 24-31. 
Scott-Clayton, J. (2012). Do High Stakes Placement Exams Predict College Success? (CCRC Working Paper No. 41). New York, NY: Columbia University, Teachers College, Community Research Center. 